\title{
2021
}

\section{A Study of Bagobo Tagabawa Folk Speech Using Murdock's and Eugenio's Classification}

\author{
Jenifer R. Tuban
}

$\underline{\text { Abstract }}$

Around 60, 000 in number, the Bagobo people constitute one of the indigenous peoples in Davao, Philippines. This study analyzes the Bagobo Tagabawa folk speech, specifically their proverbs and riddles. Also, this study aims to help in preserving the Bagobo Tagabawa folk speech and fostering a better understanding and appreciation of their life, literature, and people. The researcher analyzed the 90 proverbs and the 97 riddles in form and style using the classification of the riddles of George P. Murdock and the category of proverbs used by Damiana Eugenio. The concept of cultural anthropology by Franz Boas was employed in the study to determine the cultural contents of each literary piece of the said indigenous group. Findings reveal that the Bagobo people have rich and varied folk literature, constituting an important part of Philippine national literature that could vanish amid modernization. This study has contributed to the preservation of the cultural materials of the Bagobo Tagabawa. Thus, it is hoped that it will make it easier for non-Bagobo Filipinos and the rest of the world to know and appreciate Bagobo folk speech. Furthermore, the researcher recommends that this study be disseminated among folklore enthusiasts to enrich the Bagobo Tagabawa

Author information:

Jenifer R. Tuban jrtuban@usep.edu.ph orcid.org/0000-0002-6468-5358

Faculty of Literature, College of Arts and Sciences, University of Southeastern Philippines folk speech analysis. This research can help the National Commission on Indigenous Peoples (NCIP) promote, protect, and recognize the culture of the indigenous peoples, particularly in the territory of Mindanao.

Keywords: folk literature, Cultural Anthropology, Mindanao
literature, descriptive literary
approach, Davao City 
Folk speech, which includes riddles and proverbs, is a genre of folk literature that is a branch of the broad field of folklore. Educating succeeding generations of the vanishing oral tradition is a means to preserve the indigenous peoples' culture. Anthropologists, folklorists, and literary scholars such as Benedict (1907), Cole (1913), Hart (1964), Uranza (1969), Manuel (1980), and Eugenio (1982), have collected and studied proverbs and riddles, whether to preserve them for the next generation or to make use of them in other fields of the arts like the children's literature, games, and films. These prominent folklorists had examined oral tradition as a source of information about culture (Elbert, 1956). Boas was one of the first to make a systematic survey of culture items found in the body of oral literature. Then, there were others who followed him such as Radin (1930), Mclean (1957), and Kardiner and Preble (1963). For Bascom (1965), the folklore of the people can be fully understood only through knowledge of their culture (Ibid.). Instruction and entertainment are the primary functions of riddles, as seen from studies of riddling in Finnish, Hungarian, American Indian, Chinese, Russian, Dutch, and Filipino cultures, and can be considered a universal art (Dundes, 1976). Riddles emerge as a distinct type of literary expression in most African cultures and is considered as a unique domain of children's literature (Finnegan, 1970) and have a significant cultural, educative, intellectual, ideological, cosmological, and political role (Awedoba, 2000). Proverbs have been considered a valuable key for learning language and culture and an excellent tool for worldview studies (Niemeyer, 1982).

Due to the colonization of the Philippines during the Spanish rule, the Christianization of the early Filipinos, and the introduction of western culture, only a few cultural communities were able to keep records of their oral lore. In time, the perishable materials on which the Filipinos wrote were left to disintegrate, and those that remained were destroyed by missionaries who believed the indigenous pagan culture was the handicraft of the devil himself (Lumbera \& Lumbera, 2005).

Educating the succeeding generations of the vanishing oral traditions will lead to the preservation of the literary works and folk speech of various cultural communities. This would also provide a better understanding of the origin of these groups and the establishment of their identity through their recorded history. However, a survey on folklore and folk literature in the Philippines reveals that there are only a few studies on the minority groups like the indigenous peoples of Mindanao (Mindanao Studies Creation Foundation, 2005; Eugenio, 1985; Manuel, 1965). It is therefore imperative to conduct intensive research and studies on the oral literature of Philippine ethnolinguistic groups, which 
include the indigenous peoples of Mindanao. Intensive collection and analysis of Philippine folk literature, particularly those groups which belong to the minority groups in Mindanao like the Bagobo Tagabawa, is important to preserve and integrate them into literary and cultural studies (Manuel, 1974).

This study aims to identify the types of the Bagobo Tagabawa folk speech and analyze them in terms of content and indicate how they reflect Bagobo Tagabawa life and culture. Moreover, the significance of the proverbs and the riddles to the Bagobo Tagabawa are pointed out.

\section{Materials and Methods}

The study uses the descriptive literary approach anchored on the CulturalAnthropological Reflection Theory on Culture by Franz Boas (1929) to analyze the Bagobo Tagabawa folk speech as a reflection of the life and culture of the Bagobo Tagabawa. Boas (1929) reveals that folk speech reflects culture as it represents a systematic description of the ethnology of the people. Furthermore, the literary analysis deals only with the analysis of the form, style, and content of the folk speech. After the analysis, the researcher provides the significance of the proverbs and riddles of the Bagobo Tagabawa.

The materials used in the study are from an unpublished collection of Ma. Rita C. Tuban (2014), the project leader of the literary research entitled Tagabawa Bagobo Folk Narratives. The researcher, as the assistant study leader, and Dr. Patricia O Elbanbuena, as the study leader, went to Calinan, Davao City, to ask permission from the leaders as well as from the members of the Bagobo Tagabawa and collected their folk narratives for preservation and promotion. A total of ninety (90) proverbs and ninety-seven (97) riddles were subjected to analysis in terms of form and style and how they reflect the life and culture of the Bagobo Tagabawa. Also, the researcher consulted published sources on the Bagobo Tagabawa, particularly on their culture and folk speech, and made arrangements to interview Mr. Gilbert Ale, a Bagobo and key informant of Dr. Ma. Rita C. Tuban. The researcher read a significant number of books about the Bagobo, particularly the works of Cole (1913), Benedict (1907) on the Bagobo ethnographic data, Manuel (1962) on the Bagobo riddles, and Eugenio (1982) on Philippine Folk Literature.

The riddles and proverbs were laid out with their translations and coded with preliminary themes. The researcher then determines more encompassing emergent themes. The procedure was repeated until the themes could no longer be combined and broad categories were reached. For the classification of the riddles and proverbs, the study utilized the established classification of Murdock (1961) and the category used by Eugenio (1966) 


\section{Results and Discussion}

\section{Bagobo Tagabawa Proverbs}

The 90 proverbs collected were categorized according to the proverb groupings used by Eugenio (1966). The survey of the collection of proverbs may be thematically placed into six broad categories. First, proverbs expressing a general attitude towards life and the laws that govern life. Second, the ethical proverbs recommend particular virtues and condemn certain vices. Third, proverbs expressing a system of values. Fourth, proverbs expressing general truths and observations about life and human nature. Fifth, humorous proverbs. And the sixth category includes other proverbs that express other themes not included in the first five categories.

\section{Form and Style of the Proverbs}

In form and style, Bagobo proverbs are mostly prosaic rather than poetic statements. Common experiences of Tagabawa are connected to different factors such as physical, emotional, spiritual, moral, social, economic, and political.

\section{Use of Metaphors}

The use of metaphors was prolific in Bagobo proverbs. For example, in the proverb of the tall tree, the tree figures as a prominent metaphor for a man who is prone to excessive pride. This warns the Bagobo on the dangers of hubris and emphasizes the value of humility and roundedness. The proverb goes, "Ating ka saken menek madabu ka, madigarpa diyan ka tana dad mamudot nkatu mga idabo, madigar pa menek." (Climbing a tree to reap what you sow could cause you to fall. It is better to pick up the fruits off the ground.)

A flying bird is used as a metaphor for man, warning against excessive pride as the cause of one's eventual failure. The proverb goes, "Lumayang $k a$ lumayang anda sadunan tana giapun, ating kanda swerno madabu ka gihapon" (If you keep on flying, you will eventually strike the ground, and if you fall, you will fail miserably).

In another proverb, a book is a metaphor for the personality of a person: "Iya no sadumi tu libru para iya no siral iya tambon kato libro" (Do not judge a book by its cover). Steel is a metaphor for man, and the rust is a metaphor for his relatives or his own body: "Yakag kasuko ka mamanu ka tingud katu, tingud katuk nigo niko pamigwe. Pamatawi no anda sumira, katu kadatan; anda maka 
sari katu kamanuan, anda makasira kararing" (Do not be displeased because it leads you to perish, move on with your resentment; you should note that nothing breaks the steel; but the rust). A metaphor for a lazy man is the sleeping shrimp who is blown by the wind: "Iyan pisik ig tulog inanod kig waig" (The dormant shrimp will be blown by the wave). The bamboo is a metaphor for a humble person: "Anda Kawayan den, Kalibutan deri kabantang" (There is no bamboo in this world, which cannot bow).

\section{Form and Style of Riddles}

The researcher observed that the Bagobo are fond of singing, playing, and reciting riddles. Bagobo riddles were in couplet form, which proves that they have a poetic temperament and they love to play words for amusement. The riddles were a form of free verse and there were one, two, three, or four lines to a stanza. Bagobo Tagabawa riddles had similar sounds at the end of the line. The riddles were also in alliteration, metaphor, simile, and personification, and some were composed in two rhyming lines.

\section{Bagobo Tagabawa Riddles}

The system of riddle classification in the Outline of Cultural Materials by Murdock (1961) has been adopted by the researcher since it was a pattern that systematically organized cultural materials and classified riddles according to their solutions.

The ninety-seven (97) riddles collected were classified according to the subject matter. Mostly, the Bagobo Tagabawa riddles were a type of prose that refers to a verbal game or a contest of wits.

The Flora category deals with the riddle varieties of land and marine plants. There were eighteen (18) riddles about flora. The riddles had one example for ampalaya, balimbing, banana, coconut, chili, guava, labana, guyabano, gabi, palm leaves, tamarind, tree, trump, and upo, and two examples for onions and leaves.

Next to the Flora category was the riddle group on Dwelling and Maintenance. Fifteen (15) riddles centered on broom, cage, chair, cupboard, glass, house, ladder, lamp, platter, spear, stain, water jar, and window materials, which were familiar objects in the house of the Bagobos.

The next subject was Climate, Topography, and Celestial Bodies. The Bagobo community is on agriculture and they depend on rainfall, seasons, and the waxing and waning of the moon, like the Sorsogon region (Uranza, op. cit. p. 264 cited by Tuban, 2014). There were twelve (12) riddles on Mount Apo 
and two (2) for water, and ten (10) riddles with one example for the following: night, falls, rust, moon, star, rainbow, road, and wind. This category deals with the phenomena and cyclic processes of nature.

The subject group Fauna covered the different kinds of edible animals. There were sixteen (16) riddles under this group, with one riddle for a beetle, chick, dog, dragonfly, deer, duck, cobwebs, gills, pig, shellfish, spider, snakes, rat, and termite. On the other hand, two riddles were for firefly and there was no riddle for a cow. Also, the animals' chick, dog, duck, and pig are presumed to be eaten by the Bagobo.

Six (6) riddles were classified under the Human Biology subject group with one riddle for the following: head, finger, father, Lolo Buat, and slave. This revealed that the Bagobo are aware of their existence.

There were thirteen (13) riddles under the subject category Food Quest with one riddle for bagoong, balot, bibingka, coconut wine, fire, plow, sugared popcorn, sardines, smoke, stone, table salt, table sugar, and tobacco. This revealed that the Bagobo have delicious food like bibingka. They also like to eat bagoong, balot, popcorn, and sardines.

There were only two (2) riddles under the Games category such as pole and topper, which are among the favorite games to play of the young Bagobos.

There was only one ( 1 ) riddle under the Fine Arts subject group which was the gong. The gong is essential to the Bagobo because they use it to gather the constituencies.

For the Land, Water, and Transportation riddle group, there were two (2) riddles each for an airplane and a boat. This showed that the Bagobo also travels by airplane and boat.

There were only two (2) riddles on the subject category Religious Practices. These are church and prayer. This showed how the Bagobos value the church and prayer.

The subject category on Miscellany had only three (3) riddles: two riddles on shadow and one on Aswang.

To sum it up, the poetic vision of the riddles revealed so much about the cultural life of the Bagobo people, their flora, their dwelling equipment, their climate, fauna, clothing, and shelter through the lens of the Cultural Materials of George P. Murdock (1961). Their curiosity about their human biology was revealed in riddles about the different parts of the body. Also, these riddles are both prosaically stated or sung in verse form.

The poetic vision was invariably the common experience of the indigenous people constituting a village such as food-gathering, creatures, natures, occupations, household chores, forest and games, arts, and religion. In addition, the early Bagobos resided along seacoasts and riverbanks. The places nearby 
the major sources of food were also the most convenient transportation routes. Bagobos were occupied with labor within the place and in remote places. Most of them never leave the territory and became fishermen, jungle farmers, and hunters, versatile at finding their sources of livelihood wherever they could.

\section{Cultural Contents of Bagobo Tagabawa Folk Speech: Proverbs and Riddles}

\section{Bagobo Tagabawa Proverbs}

The Bagobos believe that all actions have consequences and their actions have corresponding repercussions. Everyone must not think of getting away with bad choices even if one does not seem to get caught. The Bagobo had been Christianized and were aware of the verses in the Bible. They believe that God sees their choices and actions and that people reap what they sow. This makes them conscious of the long-term effects of every action (Cole, 1914).

The Bagobos are following a practical, healthy lifestyle as they give importance to the physical body and its overall well-being. They always try to remember that their physical bodies are simply a temporary vehicle that the soul inhabits. On the other hand, the Bagobo Tagabawa also considers it normal to place the importance of money above own health. However, everyone never stopped to take good care of themselves and never let the goal of being rich take over the pursuit to be healthy. This contradicts the practice of other Bagobos who sometimes skip breakfast and ignore massive headaches while planting until they realize they should take better care of themselves and enjoy life in all aspects.

The twelve (12) proverbs revealed the importance of the life that encompasses love, happiness, peace, family, and the Almighty God. The realization of how beautiful a person's life is is similar to the experience of true happiness. Everyone wants peace of mind to easily accept the normal and different elements of life. A person who is capable of holding and building a life without hurting someone's feelings is the best creation. They are responsible for the fair distribution of missions that are applied in the daily routine of the Bagobo's life.

In a Bagobo Tagabawa family, the parents are responsible for molding their children through discipline and through imparting values that they should live by. The behavior of the children depends greatly on the ways the parents took charge. The Bagobos emphasize the good qualities in the proverbs. They would like to teach the new generation the goodness of honesty. They must be honest to avoid becoming troublesome. This emphasis has been supported by the 
Datu and some leaders of the society to influence other cultural communities even in remote places. Also, the Bagobo highlights another virtue that is stated practically, and this is the importance of being presentable and fragrant. Some Bagobos are in favor of proper hygiene, especially for women. The health tips are accepted by them since it teaches, especially young women, the proper physical sanitary and other related transformation of the growing appearances, making significant efforts towards beauty and cleanliness.

The proverbs denote the prominence of educating the people to become an instrument of peace, love, and prosperity. The Bagobo Tagabawa are a privileged group because they are tasked as the bearer of the glad tidings with the duty of preserving the culture that includes practices and folkways to the succeeding generations. The young generation will learn not to devote too much time to mundane, temporary things such as wealth and power; instead, they must spend their time being good and becoming an outstanding model for the generation next to them.

\section{Riddles of Bagobo Tagabawa}

The Tagabawa are a sub-group of the Bagobo and originally occupied most of the landmass at the foot of Mt. Apo, which is the highest mountain in the Philippines. The said area has been protected by Barangay authorities for developing productive agriculture. They developed a substantial part for agriculture use.

Bagobos are engaged in agriculture and they grow corn in the area. During the crop season, they harvest coconut and cocoa. During the fruit-bearing trees season, Bagobos harvest santol, guyabano, balimbing, guava, turnip, and banana. Many Bagobo farmers also grow vegetables like squash, palm leaves, beans, ampalaya, and many more.

The Bagobo's primary livelihood or principal source of income is farming. They till lands and some males of the community are wage laborers and are dependent on the demand for seasonal labor to do various farm chores. These farm chores include "magsaka Lubi' which means climbing the coconut trees and carrying the harvested coconuts to an area where they were to be de-husked and loaded in a truck for transport. Also, some Bagobo men work as harvesters of fruit-bearing trees. The Bagobo women produced vegetables and flowering plants gathered from backyard gardening and sold them at Toril Public Market and even in remote markets specifically in Davao City.

The settlement of Bagobo is traditionally composed of individual farmhouses, which are houses near their farms where water is available. 
Aside from farming, both men and women strip hemp for domestic development. They can build houses and cages using ladle, spear, and wire as mentioned in the riddle. They also have kitchen utensils like a water jar, platter, and grass. These are familiar objects found in most Bagobo homes which are used for cleaning and some are for decoration and beautification purposes such as broom, lamp, chair, cupboard, and some are parts of the common style of Bagobo houses like stairs, windows, and yard.

There are eleven (11) riddles under this subject: nine (9) riddle subjects under this category deal with the phenomena and cyclic process of nature like in the Bagobo riddles such as the wind, water, flowing water, rainbow, star, moon, mist/ rain, falls, and darkness/ night, and two (2) riddles that talk about specific places in Toril such as the Mt. Apo, which is located at Sandawa, and the road. Mount Apo in Sandawa happens to be the sacred grounds of the Bagobo since time immemorial; it is valued as one among the group's richest as well (Mangune, 2012). It is considered the highest mountain in the Philippines. Today, it is also a cultural heritage among those who are members of the Langis religious group. It is called as well as the official residence of the geothermal plant.

The riddle group on Clothing had seven (7) riddles. One (1) riddle for each on comb, hat, pillow, pin, and ring, and two (2) riddles on jewelry. This proves that Bagobos are aware of good grooming and elegance. A proof of the Bagobo artistry and craftsmanship is a Bagobo weaver named Salinta Monon who won the Gawad sa Manlilikha ng Bayan (GAMABA) award for her handloom weaving.

Emblematic Bagobo women wear a dress that is simple but colorful, same with the contemporary women, as to illustrate the ordinary attire of the women; it consists of the tube skirt and a simple blouse in which the skirts usually have a floral pattern in earthen tones like russet, orange, or burnt sienna. And it was mentioned that their blouses have short bell sleeves and simple lace edging around the neck, arms, and waist.

Occasionally, it was only during feast days and religious days that Bagobo women wore traditional clothes and jewelry. An example of cloth they make is the tinalak, a polished fabric, decorated with stones and shells to bring out a special luster and softness. Until today, the Bagobo still maintain their attire.

Even the new generation of tribal folk maintain the common styles of clothes for women and men and of their jewelry as part of their apparel. It is also true among the Bagobo that they choose their chieftain by casting their votes with such qualifications of wisdom, bravery, and respectable personality. They chose their Datu to lead and give a decision as an obligation to the tribe. $\mathrm{He}$, as the Datu, is committed to the responsibilities he had been taking for the 
sanctuary of his members' resources. He is capable of protecting his people from any destructions and different stimuli as well. The statement above proves that the Bagobos are still clinging to their old political structure of the datushipin system wherein the datu is called as their chieftain and the head of the village.

In history, the most powerful datu of the Bagobo was Datu Manib. When the Spaniards had arrived, the Datu cordially received them. But later on, he was imprisoned for defying the Spanish injunction against human sacrifices and refusing to help them capture a Bagobo fugitive (Ibid).

Another truth to the Bagobo that the researcher had discovered was the unity and active participation of Bagobos in any relevant events in their society such as the Bagkes, the final ritual of the season of harvest, the Langis festival which is a concoction of mount Apo ingredients, and the Buwis (monetary tribute) that is offered on Thursday and Sunday morning, Saturday evening and the first day of each month. Bagobo Tagabawa people administered the exposure of their cultural community by allowing any interested people to study their culture, as specifically revealed in their folk speech such as proverbs and riddles.

The Bagobos have unique, artistic talents in terms of music and arts. The creativity of the community was showcased in their barangays during events and activities.

As one of the creative and artistic cultural communities in the Philippines, the Bagobo are fond of holding festivities with merriment and music. They usually play the gong ensemble called tagungguan/tagunggo. Nowadays, the tagungguan found in Davao similarly consists of eleven (11) gongs: a set of ten (10) gongs and a large gong called bandi. There is a cylindrical drum called gibba. The ten (10) gongs are suspended vertically on a tall wooden frame with the instruments' knobbed surface facing the player (Ibid).

The Bagobos have dances in the home of the bride in the evening and the second morning after the panalugan/pamalugo (purification of the bride and groom) as mentioned in their riddles. During the garuzza (worship) where Bagobo mores dictate that the dance be initiated only by the bagani, the men dance intermittently to the sound of the gindaya during the gin-em.

The experience of the researcher as one of the research assistants during the collection of data can support the typical vehicle of the tribe in today's generation and witness the way they migrate in Sibulan, Toril, Davao City.

Bagobos believe in supernatural beings such as Ogre and shadow, as mentioned in the riddles. They are derived from the dark elements that embody evilness, sinfulness, immorality, and wickedness. They performed rituals to let the spirit of darkness part from their lives. They enlighten young minds of the good deeds to avoid the temptation that causes death. They have several 
tales about the buso, which may be considered as Marchen or fairy tales (Cole, 1913); they also believe in Mandarangan whom they considered as the God of war. Another practice of the Bagobo is called Gatok-biaan, which is the ritual performed during harvest. Also, during this feast, they invite performers to present specifically to play the guitar and the flute to entertain the rest of the Bagobos. Bagobos placed rice together with the farm tools in a big basket (Ibid). Lastly, the bagkes is the final ritual of the season of harvest. During this particular important event, there are preparations the day before the ceremonial whereas dishes are stored in the rice granary until the next festival; they are solemnly tied together with assurances to the spirits that they would be restored the following year.

\section{Significance of the Folk Speech (Proverbs and Riddles)}

The significance of the folk speech is to create sublime intentions that help the indigenous people become more cultured, more knowledgeable, and more rooted in culture. To preserve the folk speech of Bagobo Tagabawa, the researcher made an extensive and intensive analysis of the unpublished collection of the Bagobo Tagabawa folk speech with its types, cultural contents, and its significance. The researcher also emphasized the significance of the study that considerably influences the life and customs of the indigenous peoples to better understand why the people behave the way they do and must continue to practice some of their rituals.

The Bagobo proverbs are used mainly for moral instruction. They are quoted by the Bagobos when they want to emphasize the importance of something discussed but also in ordinary situations and even in casual conversation. Moreover, these proverbs are used to teach good habits, values, and right conduct.

Riddles have significant small roles. They include roles that may be described as cultural, educational, intellectual, ideological, cosmological, and political. While some studies discussed riddles as a genre looking for the capacity to improve the mind, since they involve stereotyped questions and responses, it is argued in these pages that riddles do indeed exercise the intellect more actively than the emotion and an individual's responses. Riddles teach logic, they pull audiences towards their cultural environment, and norms about history engage in the contemplation of a variety of paradoxes. They teach about the social and cultural environments about social norms, history, biology, and so much more. When the riddles are given by the adults to children, they are educating the children indirectly because the riddles make them aware of their surroundings. 
The didactic riddles which explain birth, growth, death, and natural phenomena also function as an educating agent. The riddles are compact, containing descriptions of the flora of the area and the material objects in the culture of the people. Through riddles and riddling, the children may become aware of their cultural traits. Together with the rich and colorful idiom of their language, the children may know the various aspects of their people's material and spiritual world through the poetic vision of the riddles.

\section{Conclusion}

The Bagobo Tagabawa possess folk speech such as the proverbs and riddles. The folk speech reveals much of Bagobo Tagabawa's life and culture. Their literary pieces have sounded years back and echoed until the present generation. This motivated the researcher to conduct this study to help preserve the folk speech of Bagobo Tagabawa before they vanish to oblivion. The beliefs that have been protected by the cultural group and the preservation of folkways, without a doubt, greatly influenced their way of life. Specifically, it influenced the customs and traditions of the present Bagobos. This study revealed that the BagoboTagabawa riddles and proverbs are more akin to the different cultures in the Philippines, which reminds the researcher of creating a rich cultural milieu for domestic literature.

The riddles reveal much of their cultural life. Their proverbs portray the different virtues and values that the Bagobo Tagabawa greatly cherish like kindness, self-discipline, compassion, and unity. The researcher recommends that this study be disseminated to literature students and folklore enthusiasts who can benefit from the collection and analysis of the Bagobo Tagabawa folk speech.

The riddles and proverbs in this collection significantly indicate the richness of BagoboTagabawa folk literature. However, the researcher believes that the collection was far from exhaustive because there were still many oral traditions in the field waiting to be collected by the students of the Bagobo Tagabawa culture. Thus, it is recommended that further study should be conducted on the Bagobo Tagabawa folk literature, aside from riddles and proverbs, particularly on the epic of the Bagobo Tagabawa. Future literature teachers are capable of teaching values from riddles and proverbs that contain remarkable and stand-out vision to sharpen the mental ability of their students. The Bagobos are creative externally and internally, so future researchers and faculty members should preserve the group's cultural heritage in line with the National Commission on Indigenous Peoples' mandate to promote, protect and recognize the culture of the indigenous peoples. 


\section{References}

Awedoba, A. K. (2000). An introduction to Kasena society and culture through the proverbs. African Journal Online, 16(2). https://www.ajol.info/index.php/rrias/article/ view/22895

Bascom, W. R. (1965). Functions and values of folklore for family relationship. The Journal of American Folklore, 27(307). https://www.jstor.org/stable/i223643

Benedict, L. W. (1907). Bagobo myths. The Journal of American Folklore, 26(99), $13-63$. https://www.jstor.org/stable/534786

Benedict, L. W. (1916). A study of Bagobo ceremonial magic and myth. New York. Academy of Sciences, 34(4), 137-139.

Boas, F. U. (1929). Anthropology and modern life. George Allen and Unwin, Ltd. https://doi. org/10.4324/9781003133711

Cole, F. C. (1913). The wild tribes of Davao district, Mindanao, publications of the field museum of natural history, anthropological series (Vol 12, No. 2). Field Museum of Natural History.

Cole, F. C. (1914). The Bagobo of Davao group. Philippine Journal of Science, 28(2), 125-128.

Dundes, A. (1976). Projection in folklore: A plea for psychoanalytic semiotics. Modern Language Note, 91, 1500-1533.

Elbert, S. H. (1956). The chief in hawaiian mythology. Journal of American Folklore. 69 (272), 99-113.

Eugenio, D. L. (1966). Philippine proverb lore. Philippine Social Sciences and Humanities Review, 31(3-4), 231-471.

Eugenio, D. L. (1966). Awit and korido: A study of fifty Philippine metrical romances in relation to their sources and analogues [Doctoral Dissertation, University of California].

Eugenio, D. L. (1982). Philippine folk literature scholarship: An overview. Philippine Social Science and Humanities Review, 16(2), 94-98.

Eugenio, D. L. (1985). Philippine folktales: An introduction. Asian Folklore Studies, 44(2), 157-158. https://doi.org/10.2307/1178506 
Finnegan, R. (1970). Oral literature in Africa. Oxford University Press. https://ssrn.com/ abstract $=2232995$.

Kardiner, A. \& Preble, E. (1963). They studied man. Social Forces, 42(2), 266-267. https:// doi.org/10.1093/sf/42.2.266-a

Lopez, M. (2006). A handbook of Pbilippine folklore. University of the Philippine Press.

Lumbera, B. L. \& Lumbera, C. N. (Eds.). (2005). Philippine literature: A bistory and anthology. Anvil Publishing Inc.

Lumbera, B. L. (2002). Filipinos writing. Abiva Publishing Co.

Niemeyer, L. L. (1982). Proverbs: Tools for world view studies: An exploratory comparison of the Bemba of Zambia and the Shona of Zimbabwe [Master's thesis, Portland State University]. PDXScholar. https://pdxscholar.library.pdx.edu/open_access_etds/886/

Manuel, E. A. (1962). A survey of Philippine folke epic. University of the Philippines Press.

Manuel, E.A. (1962). Bagobo riddles. Folklore Studies, 21, 1-63.

Manuel, E. A. (1965). Philippine folklore bibliography: A preliminary survey. The Journal of Asian Studies, 26(3), 547-549. https://doi.org/10.2307/2051487

Manuel, E. A. (1974). Manuvu social organization. Philippine Quarterly of Culture and Society, 2, 89-90. https://www.jstor.org/stable/29791125

Manuel, E. A. (1975). Upland Bagobo (Manuvu). In F. M. LeBar (Ed.), Ethnic groups of insular Southeast Asia Vol. 2: Philippines and Formosa. Human Relations Area Files.

Manuel, E. A. (1985). Guide for study of Philippine folklore. Philippine Folklore Society.

Mapene, S. D. (2001). Tagabawa Bagobo katutubo peoples of the Philippines cultural communities. National Commission on the Culture and the Arts.

Mclean, H. (1957). [Review of the book Russian formalism: History and doctrine, by V. Erlich]. Comparative Literature, 9, (2) 9, 189-191. https://doi.org/10.2307/1768894

Murdock, G. (1961). Outline of cultural materials. Human Relations Area Files Press. 
Radin, P. (1930). The golden mountain: Chinese tales told in California. The Journal of American Folklore, 127(506), 400-424. https://doi.org/10.5406/jamerfolk.127.506.0400

Tuban, R. (1976). Tausug folk narratives. Southeastern Philippine Journal of Research and Development, 3(2), 40-80.

Tuban, R. (2014). Folk narratives of Tagabawa Bagobo. Unpublished collection. 